\title{
A citizen's claim: Science with and for society
}

\author{
Marta Soler and Aitor Gómez
}

\begin{abstract}
:
Social science research has been attacked by neoliberal thinkers who allege that such research lacks economic objectives. In the face of neoliberal and positivist criteria for evaluating the social impact of social science inquiry, social science researchers are developing qualitative evaluation methodologies through which we can have direct contact with citizens. These qualitative methodologies declare our social responsibility as social researchers in addressing relevant problems, especially those affecting the most vulnerable people. From these qualitative methodologies, the most vulnerable groups are included in the assessment of the social impacts of social research. Some examples of people who have participated in this qualitative evaluation include women, youth, immigrants and Roma organizations. Participants perceived social science researchers as being far from their social reality, but in this research, they began to overcome their skepticism that social science research can help to solve those problems affecting their everyday lives.
\end{abstract}

Keywords: qualitative methodologies; social impact; social research; qualitative evaluation 
Men, through poetry, quickly approach the edge where the philosopher and the mathematician silently give their backs

Federico Garcia Lorca

Federico García Lorca, in a lecture preceding the public reading of the Romancero Gitano (Gypsy Ballads) in 1928, said, "If you ask me why do I say: 'A thousand crystal tambourines struck at the dawn light' let me tell you that I have seen them in the angels' and trees' hands, but I cannot say any more, far from explaining its meaning. And it's okay in that way. Men, through poetry, quickly approach the edge where the philosopher and the mathematician silently give their backs" (Garcia Lorca, 1928). The poet went beyond his poetry narrative and used to engage in dialogue with his readers about how his verses gave sense to their lives. What Lorca actually wished to transmit with these words parallels the current debate about qualitative inquiry for the assessment of social impact in social science research.

Objectivist and positivist approaches derived from neoliberal positions, which have largely been based upon research with economic goals, frequently attack qualitative methodologies for assessing social science research (Chowdhury, 2015; Ploder \& Stadlbauer, 2016). However, it has already been proven by social science research that qualitative methodologies developed from the field give us rich data that reveal profound truths about social phenomena (Monahan \& Fisher, 2010).

Social science researchers cannot restrict themselves to assessing social impact from only a positivist approach. If, as social science researchers, we would like to focus our investigation on important topics contributing to the progress of society, especially for the most vulnerable groups (O'Faircheallaigh, 2012), we need to develop qualitative tools to assess to what extent the research is having direct impact on improving those groups' living conditions (Kok and Schuit, 2012). 
This challenge responds to a commitment from social science researchers and the citizens who demand the right to access knowledge and to enjoy science financed by public money that such research must have social impact that may help to improve people's daily lives (Reale, et al. 2017).

In this way, complementarities between quantitative and qualitative methodologies for social impact assessment are being increasingly defended by some quantitative researchers who highlight the quality of qualitative research methods, which allow them to obtain more results than quantitative research could produce (Chowdhury, 2015). Other researchers have considered the importance of social science researchers' efforts to always have social actors in mind when developing fieldwork to evaluate the social impacts of research in greater depth (Puigvert, Valls, García-Yeste, Aguilar, \& Merrill, 2017; Wieviorka, 2011).

For more than a decade, it has been advocated that scientific policies should go beyond the evaluation of research results with quantitative methods and contribute to the development of a more explicit alliance with qualitative methods. In this way, a deeper engagement among science, policy and the social sciences is encouraged, and the relationship between science and society is strengthened (Mitcham, 2007). International debates must be open to using different approaches to knowledge, including postcolonial and northern sociologies of knowledge as well as indigenous and southern perspectives of knowledge (Connell, Collyer, Maia \& Morrell, 2017).

Areas such as health or environmental research have an advantage in this matter. Therefore, it is typical that in a health impact assessment, qualitative methodologies are applied, which include the perceptions and expectations of the affected individuals, providing new knowledge that contributes to the progress of health research (Serrano et al., 2014). Similarly, environmental research has for decades included the perspective of people who live in or otherwise use the area affected by an environmental project. The community is included in planning, evaluating and mitigating adverse impacts of implemented projects in this community (Connor, 1998; Stolp, Groen, Van 
Vliet \& Vanclay, 2012; Toro, Requena, Duarte, and Zamorano, 2013; Diduck, Pratap, Sinclair, and Deane, 2013). From this perspective, environmental research has made a special point of including the voices of the most vulnerable groups, such as cultural minorities or indigenous people, in the impact assessment to improve decision making, promote equity, and create opportunities for sustainable development (Diduck, Pratap, Sinclair, and Deane, 2013; Hanna, Vanclay, Langdon \& Arts, 2016).

As social science researchers, creating and including qualitative inquiries for evaluating the social impact of the research is not only our responsibility but also a citizen's claim. The citizenship claims for a research that contributes to overcoming relevant social problems as well as research that is planned not only for society but with society, working together (Reale, et al. 2017).

This special issue is framed in the $7^{\text {th }}$ Framework Project IMPACT-EV, Evaluating the Social Impact of the Research, which was founded by the European Commission (Flecha, 2014-2017). The following 15 articles that form this special issue analyze how the social impact of research can be assessed using qualitative methodologies. From these 15 articles, 6 are directly linked with research results extracted from IMPACT-EV: 1) "Qualitative Inquiry: a key element for the social impact assessment of research"; 2) "SIOR: An egalitarian Scientific Agora"; 3) "WIEGO: Communicative daily life stories to assess social impact in the lives of informal workers"; 4) "The best diagnosis is the autopsy, but it comes too late"; 5) "The scientific self-literacy of ordinary people: Scientific Dialogic Gatherings"; 6) "Media manipulation against social justice researchers: second-order sexual harassment".

A qualitative evaluation of social impact has been established through dialogue among the researchers and the different groups involved in the results of the investigations presented on this special issue. These groups have access to knowledge and to the investigation results, and they can jointly assess the impacts that the latter is having on their day-to-day lives (Puigvert, Valls, García-Yeste, Aguilar, \& Merrill, 2017). 
In this way, following the words of another great Spanish poet, Gabriel Celaya, and his poetry, "Poetry is a gun charged of future"; we need to break with the cultural elitism, work with poor communities, and work against disengaged people who do not take part until they get dirty: "Poetry for the poor one, needed poetry as the daily bread (...) I curse the poetry conceived as a cultural luxury by the neutrals ones who, washing their hands, doesn't want to know and escape. I curse the poetry from who doesn't take sides till they get dirty" (Celaya, 1975).

This special issue is an example of how we can work with and for society, taking part until we get dirty because, as Paulo Freire wrote, "in being in favor of something or someone, I am necessarily against someone. Thus, it is necessary to ask: 'With whom am I? Against what and whom am I?'”(Freire, 2000: 40).

The first article of this special issue "Qualitative Inquiry: a key element for the social impact assessment of research", highlights the need for adequate analyses to comprehensively assess impact. Positivist approaches have evaluated social science research based on its economic objectives, using only quantitative data. It is necessary to use qualitative approaches to evaluate the social impact of research, conducting research through a dialogue with the public. The article introduces the IMPACT-EV research project from the $7^{\text {th }}$ Framework Programme, which was funded by the European Commission, reinforcing the fact that it is fundamental to introduce qualitative approaches to evaluate the social impact of research worldwide.

The second article "SIOR: An egalitarian Scientific Agora", introduces SIOR, a new open repository created under the umbrella of IMPACT-EV research project, which could be a very powerful international and egalitarian scientific public space. This repository has been designed to allow researchers to link their social impacts with research institutions and citizens. SIOR has become a qualitative tool with an open peer review that allows citizens to comment online about the impacts that an investigation had or is having on society. 
The third article presents "WIEGO: Communicative daily life stories to assess social impact in the lives of informal workers". WIEGO is a global network with the aim of securing financial support for people with low-income jobs, especially women, in the informal economy. Social science researchers involved in this network created spaces for dialogue and collected workers' stories about impact through diverse qualitative tools in different contexts. This article analyzes how the social science researchers working at WIEGO are impacting the lives of informal workers through communicative daily life stories.

The fourth article, "The best diagnosis is the autopsy, but it comes too late", presents how researchers need to carry out research that contributes to overcoming poverty and exclusion and not just research examining the current realities. The public wants solutions and not just a diagnosis of current problems, which perpetuates the situation of vulnerability for many people. From a communicative case study developed in one of the most deprived neighborhoods of Spain, researchers, neighbors and different social actors have contributed to analyzing actions that are successfully improving the living conditions in this community.

The fifth article is centered in "The scientific self-literacy of ordinary people: Scientific Dialogic Gatherings". Movements regarding democratizing expert knowledge are maturing, creating tools that could be used for the scientific literacy of the public. This article presents dialogues among researchers and people with low socioeconomic and educational levels regarding the social impact of dialogic scientific gatherings (based on a communicative and qualitative approach) as a tool of scientific self-literacy that is being developed in an urban adult school in Spain.

The sixth article, "Media manipulation against social justice researchers: second-order sexual harassment", analyzes a specific case of media manipulation aimed at silencing the brave people who dared to break the silence about gender violence at Spanish universities and turn the universities into spaces free of violence. Using communicative methodology, 
the authors explore the lives of the friends and relatives of these brave people who suffered second-order sexual harassment by some in the media. It is demonstrated that the group increased their social impacts; transformed the universities; and gained the support of most journalists, their family members and social movements.

The seventh article, "The Debate about the Human Papilloma Virus Vaccine: The Impact of an Evidence-based Communicative Method on Increasing Free Choice", provides an in-depth analysis of how it is possible to enhance the freedom to make decisions through an evidence-based dialogue between researchers and citizens. This article shows how a female researcher conducted communicative focus groups and communicative daily life stories where she shared existing evidence about the prevention of HPV; at the same time, women involved assessed the impact of these evidence-based dialogues, which can increase their opportunity to make a free choice about the HPV vaccine.

The eighth article, "Exploring the Impact of Dialogic Literary Gatherings on Students' Relationships with a Communicative Approach", explores the critical role of qualitative inquiry in disclosing the uniqueness of each child's experience in two dialogic learning environments. Both spaces, named interactive groups and dialogic literary gatherings, are based on solidarity-based relationships between all the children, which impact the daily lives of each participant. Qualitative inquiry serves to unveil these processes of solidarity, where quantitative approaches will never arrive.

The ninth article, "Communicative Daily Life Stories: Raising Awareness about the Link between Desire and Violence", explores how some girls, after an intervention known as 'dialogic feminist gatherings' based on the language of desire, are encouraged to question the attractiveness of violent behaviors and deeply analyze how the language of desire regarding affective and sexual relationships influences their desires and choices. The article goes into depth about on how communicative daily life stories allow researchers to assess the impact of the gatherings on identifying and questioning participants' preferences for boys with violent behaviors. 
The tenth article, "They are not Romeo Pimps, they are Traffickers: Overcoming the Socially Dominant Discourse to Prevent the Sex Trafficking of Youth”, shows how the use of the language of desire in qualitative research allows for the questioning of the standardized use of terms such as lover boys or Romeo pimps in research, preventive programs and society. These terms implicitly reproduce the desire and attraction of these violent recruiters and therefore the vulnerability of young girls towards sex traffickers. Using qualitative tools and the language of desire, it is possible not only to identify the riskiness of these desires but also to provide tools to overcome it.

The eleventh article, "Dialogue with Educators to Assess the Impact of Dialogic Teacher Training for a Zero-Violence Climate in a Nursery School", notes that there are quantitative analyses examining the persistence of being an aggressor throughout the different educational stages and its relationship with criminal behavior in youth and adulthood, but there are no qualitative studies that analyze this question in depth. This article analyzes the impact of dialogic teacher training in an urban nursery in Spain through in-depth interviews of teachers at the school, showing positive impact in terms of a zero-violence climate in the nursery after the implementation of this training.

The twelfth article, "The Impact of Radical Love on Human Memory", introduces us to a comprehensive understanding of human memory through a qualitative analysis of the impact of the book Radical Love. The article shows the importance of qualitatively examining the meanings constructed by young females. The authors applied in-depth interviews and a communicative focus group to a group of young females, analyzing the impact of the book on their memories and showing a powerful effect in terms of rejecting violent relationships and transforming their prospective thinking.

The thirteenth article, "Supporting Democracy through Leadership in Organisations", analyzes in-depth the importance of dialogic leadership in terms of increasing the social impact of a workers' cooperative. Through a qualitative analysis of cooperative organizations, the author establishes how successful cooperativist actions play a key 
role in the development of more democratic organizations.

The fourteenth article, "The Dialogic Public Policy: a Successful Case", introduces the concept of dialogic public policy as a way to fight against the social exclusion that the Roma people are suffering in Catalonia. The Roma community claimed their participation in public policies in which they were the target population, as they argued that "nothing about us without us". This article presents how politicians, researchers and the Roma community worked together using transformative scientific research to design, implement and evaluate public policy in the framework of the 3rd Integral Plan of the Roma People (2014-2016) of Catalonia.

The last article of this special issue, "The Impact of Alternative Audiovisual Products on the Socialization of the Sexual-Affective Desires of Teenagers", gives us a critical qualitative analysis of some audiovisual products for teenagers. Dominant audiovisual products link attraction and desire with violence, having a negative impact on consumers. However, there are also alternative audiovisual products that link the language of desire to egalitarian and non-violent relationships. This article uses communicative methodology to analyze the positive impacts that these alternative audiovisual products have on teenagers' sexual-affective desires.

All of these articles emphasize the importance of working together, citizens and researchers, in order to change the world. These works are not merely related to the evaluation of the social impact of research. Their importance is greater than that; it is question of social justice and human rights. As Denzin and Giardina (2009: 13) noted, we are no longer to just 'interpret' the world (...) we are called to 'change' it in ways that resist injustice while celebrating freedom and full, incisive, participatory democracy. 


\section{References}

Bryant, JM. (2000). On sources and narratives in historical social science: a realist critique of positivist and postmodernist epistemologies. British Journal of Sociology, 51(3), 489-523.

Celaya, G. (1975). La poesía es un arma cargada de futuro [Poetry is a weapon loaded with the future. In Cantos Íberos. Madrid: Ediciones Turner, S.A.

Chowdhury, MF. (2015). Coding, sorting and sifting of qualitative data analysis: debates and discussion. Quality \& Quantity, 49(3), 1135-1143, doi: 10.1007/ s11135-014-0039-2

Connell, R., Collyer, F., Maia, J., \& Morrell, R. (2017). Toward a global sociology of knowledge: Post-colonial realities and intellectual practices. International Sociology, 32(1), 21-37. DOI: 10.1177/0268580916676913

Connor, DM. (1998). Participative social impact assessment and management cross cultural application. Impact Assessment and Project Appraisal, 16(1), 65-69,doi: $10.1080 / 14615517.1998 .10590188$

Denzin, N. \& Giardina, M. (2009). Qualitative Inquiry and Social Justice. Walnut Creek, CA: Left Coast Press, Inc.

Diduck, A., Pratap, D., Sinclair, A., \& Deane, S. (2013). Perceptions of impacts, public participation, and learning in the planning, assessment and mitigation of two hydroelectric projects in Uttarakhand, India. Land Use Policy, 33, 170-182, http:// dx.doi.org/10.1016/j.landusepol.2013.01.001

Flecha, R. (2014-2017). IMPACT-EV. Evaluating the impact and outcomes of European SSH Research. 7th Framework Programme European Commission.

Freire, P. (2000). Pedagogy of the heart. New York: Continuum.

García Lorca, F. (1980). Prosa. Madrid: Alianza editorial.

Hanna, P., Vanclay, F., Langdon, E. J. \&Arts, J. (2016). The importance of cultural aspects in impact assessment and project: developmentreflections from a case study of a hydroelectric dam in Brazil. Impact Assessment and Project Appraisal, 34(4), 306-318. DOI. 10.1080/14615517.2016.1184501

Kok, MO., \& Schuit, AJ. (2012). Contribution mapping: a method for mapping 
the contribution of research to enhance its impact. Health Research Policy and Systems, 10:21. https://doi.org/10.1186/1478-4505-10-21.

Mitcham, C. (2007). Qualitative Science Policy. Qualitative Health Research, 17(10), 1434-1441.DOI: 10.1177/1049732307308951

Monahan, T., \& Fisher, JA. (2010). Benefits of "Observer Effects": Lessons from the Field. Qualitative Research, 10(3), 357-376.doi: 10.1177/1468794110362874

O'Faircheallaigh, C. (2012). Effectiveness in Social Impact Assessment: Aboriginal Peoples and Resource Development in Australia. Impact Assessment and Project Appraisal, 27, 2, 95-110.

Ploder, A. \& Stadlbauer, J. (2016). Strong Reflexivity and Its Critics. Responses to Autoethnography in the German-Speaking Cultural and Social Sciences. Qualitative Inquiry,22(9) 753-765. DOI: 10.1177/1077800416658067.

Puigvert, L., Valls, R., García-Yeste, Y., Aguilar, C. \& Merrill, B. (2017). Resistance to and Transformations of Gender-Based Violence in Spanish Universities: A Communicative Evaluation of Social Impact. Journal of Mixed Methods Research, First published date: September-28-2017. DOI: 10.1177/1558689817731170

Reale, E., Avramov, D., Canhial, K., Donovan, C., Flecha, R., Holm, P., Larkin, C., Lepori, B., Mosoni-Fried, J., Oliver, E., Primeri, E., Puigvert, L., Scharnhorst, A., Schubert, A., Soler, M., Soòs, S., Sordé, T., Travis, C., Van Horik, R. (2017). A review of literature on evaluating the scientific, social and political impact of social sciences and humanities research. Research Evaluation, 1-11 doi: 10.1093/reseval/rvx025

Serrano, E., Larrañaga I., Sanz Tolosana E., Baixas MD., Basterrechea, M., Conde, F.,\& Aldasoro, E. (2014). Health impact assessment of regeneration projects in Pasaia bay (Spain): perceptions of the affected population. Gaceta Sanitaria, 28(6), 442-449. doi: 10.1016/j.gaceta.2014.06.009

Stolp, A., Groen, W., Van Vliet, J. \&Vanclay, F. (2012). Citizen values assessment: incorporating citizens' value judgements in environmental impact assessment. Impact Assessment and Project Appraisal, 20(1), 11-23. DOI: $10.3152 / 147154602781766852$

Toro, J., Requena, I., Duarte, O., \&Zamorano, M. (2013). A qualitative method proposal to improve environmental impact assessment. Environmental Impact 
Assessment Review 43, 9-20. http://dx.doi.org/10.1016/j.eiar.2013.04.004.

Wieviorka, M. (2011). Evaluation, research and demonstration inthe socialsciences. Social Science Information Sur Les Sciences Sociales, 50(3-4), 308-316, doi: 10.1177/0539018411411016 